\title{
Influence of Deltamethrin and Cypermethrin on the Expression of SUMO Isoforms and UBC9
}

\author{
Vidhya Yarahalli Jaiprakash ${ }^{1}$, Baggavalli Somesh ${ }^{2}$, \\ Divijendra Natha Sirigiri Reddy ${ }^{1}$, Rajyalakshmi Malampati ${ }^{1 *}$ \\ ${ }^{1}$ Department of Biotechnology, BMS College of Engineering, Bengaluru 560019, India \\ ${ }^{2}$ Connexios Life Sciences Pvt Ltd, Bengaluru 560004, India
}

Received: 30 January 2017

Accepted: 18 July 2017

\begin{abstract}
Deltamethrin and cypermethrin are extensively used insecticides to which humans are widely exposed. The present study is designed to analyze the effects of these two pesticides on HePG2 cell lines and on differentiated 3T3-L1 and $\mathrm{C} 2 \mathrm{C} 12$ cells with respect to the expression of small ubiquitinlike modifiers (SUMO) and SUMO-conjugating enzyme UBC9. Treatment of HePG2 cells with either deltamethrin or cypermethrin caused elevated mRNA levels of SUMO 2 and 3 as well as UBC9. This was associated with elevated nitric oxide and nitric oxide synthase mRNA levels and decreased NADPH levels. Differentiated 3T3-L1 cells treated with either deltamethrin or cypermethrin led to increased mRNA levels of inflammatory cytokines IL-I $\beta$ and IL-6, indicating that these pesticides promote the inflammatory response. These observations are significant since previous studies reported that UBC9 and SUMO isoforms are upregulated in many types of cancers and hence the extensive use of these pesticides is a concern.
\end{abstract}

Keywords: SUMO isoforms, UBC9, deltamethrin, cypermethrin

\section{Introduction}

SUMOs are a family of proteins that are similar in structure to ubiquitin [1-2]. In humans, five isoforms (SUMO1, SUMO2/3, SUMO4, and SUMO5) have been identified so far [3-4]. SUMOs covalently conjugate to the target proteins (SUMOylation), a process that requires several enzymes, including the ubiquitin-conjugating enzyme UBC9, which is known to be conserved throughout

*e-mail: mrlbmsce@gmail.com the eukaryotes. SUMO attachment is transient as specific proteases cleave the target from SUMO $[3,5]$. It is well established that SUMO modification occurs for a large number of proteins [6] and the SUMO isoforms exhibit target preferences [7]. Oxidative, osmotic, and heat shock stresses modulate overall cellular SUMOylation pattern [8-10]. SUMOylation imbalance is reported in cancer and neurodegenerative disease [11-12]. Altered SUMO2/3 modification of 15 different targets is reported in breast cancer [13].

High expression of UBC9 is associated with lung, breast, ovarian, head, and neck cancers [14-18]. Guo et al. reported that overexpression of SUMO1 occurred in 
hepatocellular carcinoma clinical samples and that the SUMO1-SiRNA inhibited cancer cell proliferation [19].

Around 520 tons of pyrethroids are used as insecticides worldwide [20]. Deltamethrin and cypermethrin are Type II synthetic pyrethroids [21], to which humans are widely exposed through dietary and nondietary modes [22]. Deltamethrin causes high expression of metallothioneins [23], inhibition of osteoclast differentiation [24], and endocrine disruption [25-26]. Cypermethrin is known to cause impairments in seminiferous tubule structure and spermatogenesis in rats associated with reduced androgen receptor expression (27) and neurodegeneration [28]. Cypermethrin is also reported to cause developmental delays and chromosomal aberrations [29].

It is of interest to see if an extensive use of pesticides has any consequence in enhanced expression of SUMO proteins. In this study, we demonstrate that deltamethrin and cypermethrin affect the expression of SUMO isoforms and UBC9 in hepatic and adipocyte cells (HePG2, 3T3-L1 cell lines) in addition to triggering oxidative stress.

\section{Materials and Methods}

\section{Cell Lines and Reagents}

Human hepatocarcinoma cells (HePG2), mouse embryonic fibroblast pre-adipocytes (3T3-L1), and myoblasts $(\mathrm{C} 2 \mathrm{C} 12)$ were obtained from ATCC. Deltamethrin (N-11579) and cypermethrin (N-11061) were purchased from Chem Service Inc., USA. MEM (cat No. M0643), DMSO (D2438), Trypsin, DPBS (Dulbecco's PBS), MTT, Trizol reagent, IBMX (Isobutyl-1-methylxanthine), Hoechst B33258, Griess reagent, and DCF (dichlorofluorescein diacetate) were purchased from Sigma. FBS (Foetal bovine serum), and Penicillin- streptomycin were purchased from Gibco. Dexamethasone (RM4185) and DMEM (AT183) were obtained from Himedia. I script cDNA synthesis kit (1708891) and Bradford reagent were purchased from Bio-Rad. Primary antibodies purchased were: antiSUMO1 antibody from 'Sigma' (cat No. S8070-200UL), anti-UBC9 antibody from 'Cell Signaling Technology' (cat No. 4918S), and anti- $\beta$-actin antibody from 'Santa Cruz Biotechnology' (cat No. sc-47778). PCR- kit was purchased from Kappa labs (SYBR Fast 2X qPCR Master Mix) and ECL- Kit (cat No. 32209) was purchased from Thermo scientific.

\section{Cell Culture}

HePG2 cells were cultured in MEM supplemented with $3.5 \mathrm{~g} / 1$ glucose and 10\% FBS. 3T3-L1 cells were cultured in DMEM supplemented with 10\% FBS and $3.5 \mathrm{~g} / 1$ glucose. Post-confluent monolayers were subjected to differentiation into adipocytes in the presence of differentiation medium for the first three days (DMEM supplemented with 500 $\mu \mathrm{M}$ IBMX, $1 \mu \mathrm{M}$ Dexamethasone, and $100 \mathrm{nM}$ Insulin), followed by maintenance medium (DMEM with $100 \mathrm{nM}$ insulin) for the next four days and in culture medium until day 15 . C2C12 cells were cultured in DMEM supplemented with $3.5 \mathrm{~g} / 1$ glucose and $10 \%$ FBS. They were differentiated into myotubes by reducing FBS to $2 \%$ for seven days. All media contained $100 \mathrm{mg} / \mathrm{ml}$ streptomycin and $100 \mathrm{U} / \mathrm{ml}$ penicillin. Treatment with pesticides was carried out for $24 \mathrm{hrs}$. 3T3-L1 and $\mathrm{C} 2 \mathrm{C} 12$ were differentiated before treatment.

\section{MTT Assay}

For the cytotoxicity assay, cells were seeded into 96 well plates (3T3-L1 and C2C12 were on the 15th and 7 th days of differentiation, respectively) and were grown to $70-80 \%$ confluence. After 24-hour treatment with either deltamethrin or cypermethrin, $10 \mu \mathrm{l}$ of MTT solution was dispensed into each well $(5 \mathrm{mg} / \mathrm{ml}$ PBS) and incubated at $37^{\circ} \mathrm{C}$. The purple formazan crystals formed were dissolved by adding DMSO. OD 560/OD $670 \mathrm{~nm}$ [30] was calculated. Six replicas were maintained for each concentration. $\mathrm{IC}_{50}$ values for each chemical were calculated and concentrations below the $\mathrm{IC}_{50}$ were used for further experiments

\section{Estimating ROS and NADPH}

Reactive oxygen species (ROS) was estimated by the Dichlorofluorescein diacetate (DCF) method [31]. After treating cells for 24 hours with deltamethrin or cypermethrin, DCF dye was added $(20 \mu \mathrm{M})$ in phenol-red free medium, incubated for one hour at $37^{\circ} \mathrm{C}$, and $\mathrm{OD}$ was read at 485/528 $\mathrm{nm}$. The readings were normalized with that of DNA (read after one-hour incubation with $10 \mu \mathrm{M}$ Hoechst). In the case of 3T3-L1 and $\mathrm{C} 2 \mathrm{C} 12$, cells were differentiated prior to treatment with the pesticides. For NADPH estimation, autofluorescence of the cell lysates was read at 340/420 $\mathrm{nm}$ [32].

\section{Nitric Oxide Estimation}

Spent media from cell cultures treated with deltamethrin or cypermethrin were mixed with equal volumes of Greiss reagent and incubated for $10 \mathrm{~min}$ at RT. Absorbance was measured at $540 \mathrm{~nm}$ [33]. Sodium nitrate was used as standard, and Bradford assay was performed to estimate protein for normalization.

\section{Quantitative PCR}

For real-time qPCR, RNA was extracted from cells using Trizol reagent, followed by chloroform-isopropanol precipitation and washing with $75 \%$ ethanol. cDNA synthesis was done by using i Script cDNA synthesis kit as per manufacturer's protocol. Gene-specific amplification was done using SYBR Fast 2X qPCR Master Mix as per the protocol. The primers used were as follows (5-3'): human GAPDH-FP (ggctgcttttaactctggcaaa) and RP(gtgggtagaatcatactggaacatgt); human NOS2A-FP 
(acaagcctacccctccagat) and RP(tcccgtcagttggtaggttc); mouse 18S RNA-FP (ggacacggacaggattgaca) and RP (cgctcca ccaactaagaacg); mouse IL1 $\beta-F P$ (acatcagca cctcacaagca) and RP (gcattagaaacagtccagccca); and mouse IL6-FP (gccttcttgggactgatgct) and RP (agacaggtctg ttgggagtgg). Human SUMO1-FP (tgtggggaagggagaaggat) and RP (aaggttttgectcctggtca), human SUMO2-FP (atgaaagcctatt gtgaacg) and RP (cttcatcctccatttccaac); human SUMO3-FP (gagaggcagggcttgtcaat) and RP (gaacacgtcgatggtgtcct); human UBC9-FP (cgaaccaccattattcacc) and RP (ggatctgtttgattgtga tgg); and mouse SUMO1-FP (ctccgaaagaactgggaatgga) and RP (ctaaaccgtcgagtgacccc). Mouse SUMO2-FP (gggacaggatggttctgtgg) and RP (ttccaactgtgcaggtgtgt); mouse SUMO3- FP (cccaaggagggtgtgaag ac) and RP (ttgaactgtaccaccgagcc); and mouse UBC9-FP (ctgtctctgcc actggaaact) and RP (cactacggtggettggata).

\section{Statistical Analysis}

A minimum four replicas were maintained for each concentration and the experiment was repeated twice. Statistical analysis was performed by column statistics in graph pad prism.

\section{Results and Discussion}

To determine the $\mathrm{IC}_{50}$ value of deltamethrin and cypermethrin to the cell lines under testing (HepG2, 3T3-
L1, and C2C12), MTT assay was performed after being treated with either of the pesticides for 24 hours. As shown in Figs 1(a-f), cell viability is reduced in a dose-dependent manner. HePG2 and 3T3-L1 cell lines show $\mathrm{IC}_{50}$ between 200-250 $\mu \mathrm{M}$ concentrations for both deltamethrin and cypermethrin. These chemicals were less toxic to $\mathrm{C} 2 \mathrm{C} 12$ cells compared to HePG2/ 3T3-L1. Concentrations much below $\mathrm{IC}_{50}$ were used for further experiments.

Increased reactive oxygen and nitrogen intermediates can lead to many pathological conditions. In order to study the extent of oxidative stress caused by these pesticides, we measured the ROS/nitric oxide/mRNA levels of nitric oxide synthase $2 \mathrm{~A}$ (NOS2A)/NADPH in (HePG2), differentiated muscle cells (C2C12) and mature adipocytes (3T3-L1). Deltamethrin and cypermethrin caused an increase in ROS and NO accompanied by elevated NOS2A mRNA as well as reduced NADPH levels in HePG2 cells (Figs 2a-f). In differentiated 3T3L1, concentration-dependent increases in NO levels accompanied by a drastic decrease in NADPH levels (Figs. $3 a-b)$ were observed. A similar pattern was observed in C2C12 (Figs 3c-d). Proinflammatory cytokines such as interleukin-1 $\beta$ (IL-1 $\beta$ ) and interleukin-6 are reported to be elevated in a number of metabolic disorders [34-35]. Our study shows that both deltamethrin and cypermethrin cause a significant increase in mRNA levels of IL-6 and IL-1 $\beta$ in 3T3-L1 cells (Figs 3e-f).

SUMO isoforms and UBC9 are known to be elevated in certain cancers $[13,16,19]$. Hence, we studied the influence of these pesticides on the expression of SUMO

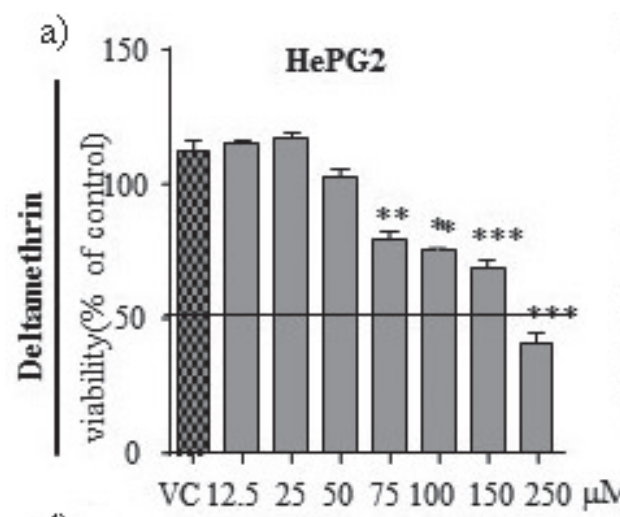

d)

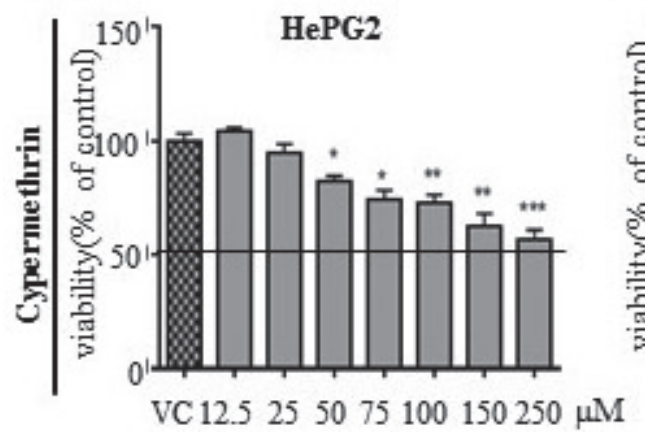

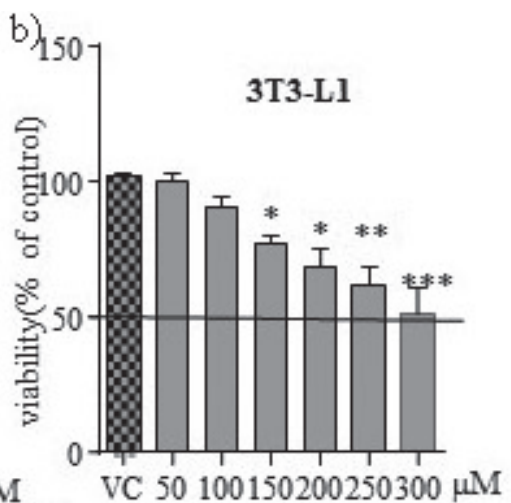
e)

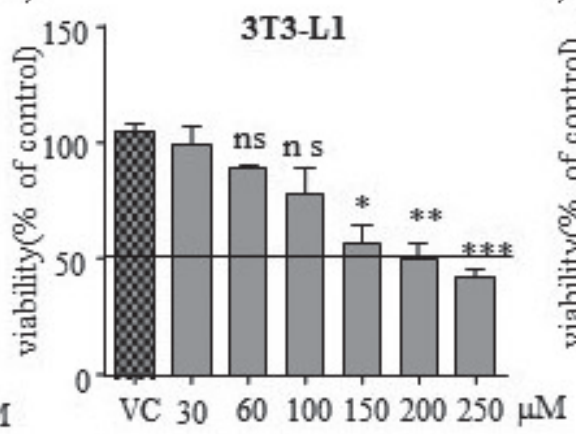

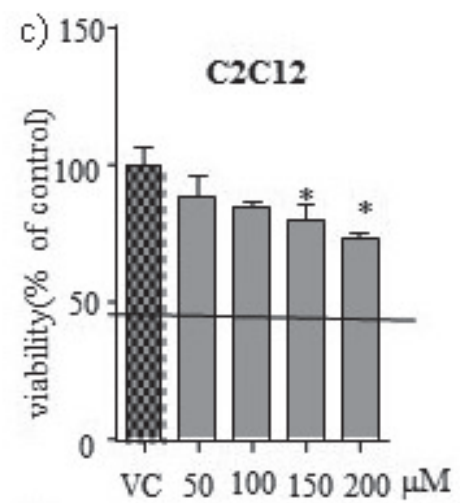

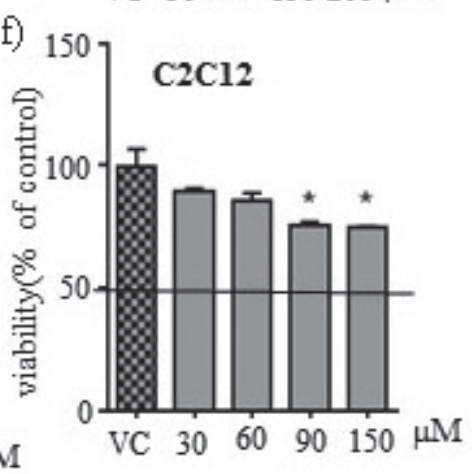

Fig. 1. Cell viability assay by MTT: a) HepG2 cell lines, b) differentiated 3T3-L1, c) differentiated C2C12 induced with deltamethrin for 24 hrs., and d-f) HePG2, differentiated 3T3L1, and differentiated C2C12, respectively, exposed to cypermethrin. Data are expressed as mean \pm SEM, and statistical analysis was performed using the unpaired Student's t-test $\left({ }^{*} \mathrm{P}<0.05, * * \mathrm{P}<0.01,{ }^{*} * \mathrm{P}<0.001\right.$ and $\left.\mathrm{n}=4\right)$. 
HePG2

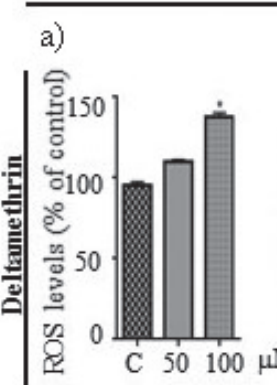

b)

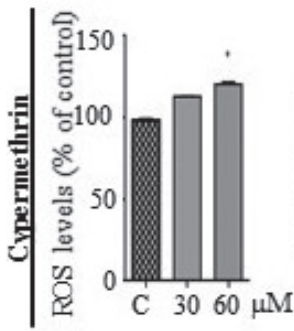

d)
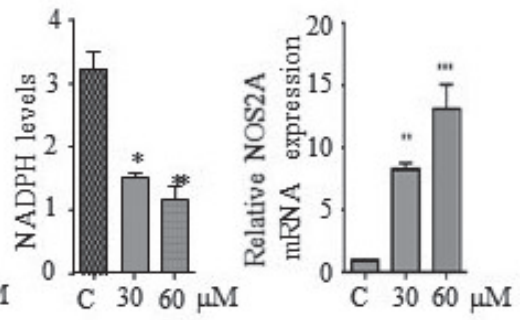

Fig. 2. Deltamethrin and cypermethrin cause oxidative stress in HePG2 cell lines: a) and b) refer to ROS levels on exposure to deltamethrin and cypermethrin, respectively. c) and d) refer to NADPH levels on exposure to deltamethrin and cypermethrin, respectively. e) and f) refer to the expression of NOS2A gene relative to GAPDH mRNA. Gene expression was quantified by RT-PCR and the data expressed as mean \pm SEM. Statistical analysis was performed using the unpaired t-test. $(\mathrm{n}=4, * \mathrm{P}<0.05$, $* * \mathrm{P}<0.01, * * * \mathrm{P}<0.001)$

isoforms (1-3) and UBC9. In HePG2 cells, SUMO2 mRNA levels increased upon treatment with deltamethrin, whereas both SUMO2 and 3 mRNA levels were increased with cypermethrin. There was no significant change in mRNA expression of SUMO1 in these cell lines. UBC9 levels also were elevated in HePG2 cells upon treatment with deltamethrin and cypermethrin (Figs 4a-b).

In 3T3-L1 cells, treatment with cypermethrin led to elevated mRNA levels of SUMO1 and SUMO2 (Fig. 4d), with no significant changes in UBC9 mRNA levels. In differentiated $\mathrm{C} 2 \mathrm{C} 12$ cells, no significant increase or decrease was observed in mRNA expression levels of SUMOs except in SUMO3 (cypermethrin) (Figs. $4 \mathrm{e}-\mathrm{f})$.

The effects of deltamethrin and cypermethrin on immune, reproductive, and nervous systems have been documented [23, 36-37]. Deltamethrin is sprayed for control of malaria in endemic areas. Its concentration in some soils was found to be as high as $8.9 \mathrm{mg} / \mathrm{kg}$. In children living in sprayed houses, the urinary concentration of 3-PBA and $\mathrm{Br}_{2} \mathrm{CA}$ (metabolites of deltamethrin) were found to be $27.3 \mu \mathrm{g}$ and $60 \mu \mathrm{g}$ per gram of creatinine, respectively [38]. So far, there are no reports available on how these pesticides influence the expression of proteins involved in SUMOylation. Such studies are required in view of the fact that SUMO modification occurs to a large number of cellular proteins and SUMOylation plays an important role in many cellular processes [39-40]. It was previously demonstrated that oxidative stress induced by $\mathrm{H}_{2} \mathrm{O}_{2}$ led to high levels of free SUMO1 accumulation in HeLa cells [41]. Likewise, in mammalian cells, nitric oxide accumulation caused global hypo-SUMOylation of SUMO1 and SUMO2/3 [42]. In our study we observed that oxidative stress being developed upon treatment with these two pesticides was accompanied by higher a)
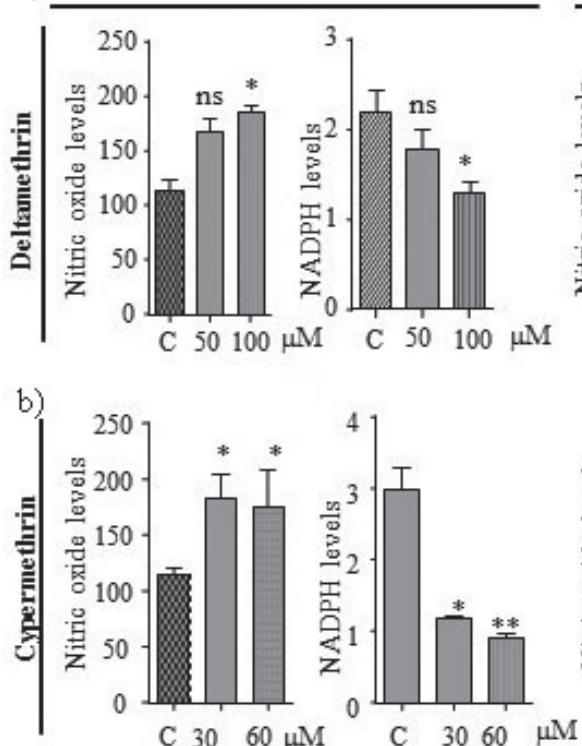

c)

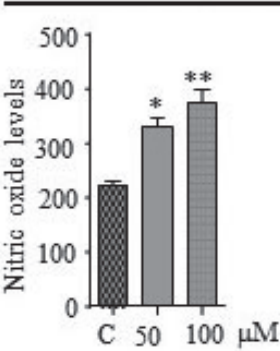

d)

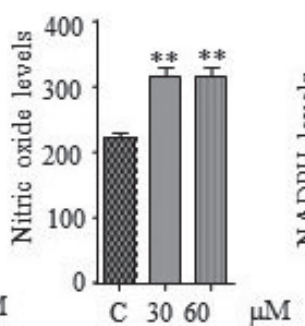

$\mathrm{C} 2 \mathrm{Cl2}$
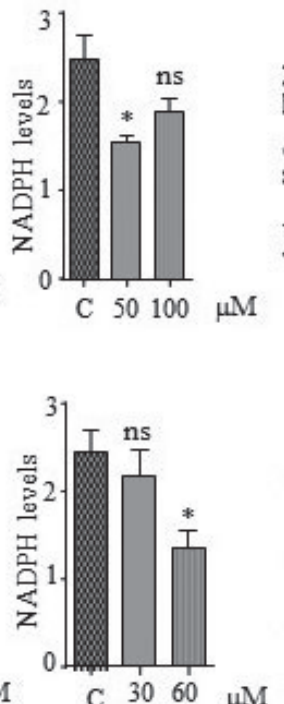

e)

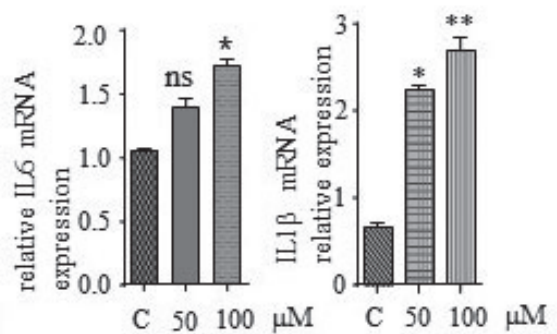

f)

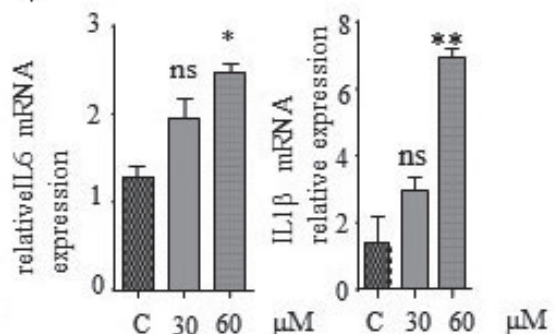

Fig. 3. (a-d) Deltamethrin and cypermethrin caused an increase in nitric oxide levels and a decrease in NADPH in differentiated 3T3L1 and $\mathrm{C} 2 \mathrm{C} 12$ cells: $\mathrm{NO}$ was estimated in spent medium and $\mathrm{NADPH}$ levels were estimated in cell lysates $(\mathrm{mean} \pm \mathrm{SD} ; *=\mathrm{p}<0.05, * *=$ $\mathrm{p}<0.01$ and $\mathrm{n}=4$ ). (e and $\mathrm{f}$ ) Effect of deltamethrin and cypermethrin on mRNA levels of IL1 $\beta$ and IL6 in differentiated 3T3L1cells as quantified by real time q RT-PCR. $(\mathrm{n}=4, *=\mathrm{P}<0.05, * *=\mathrm{P}<0.01)$. 

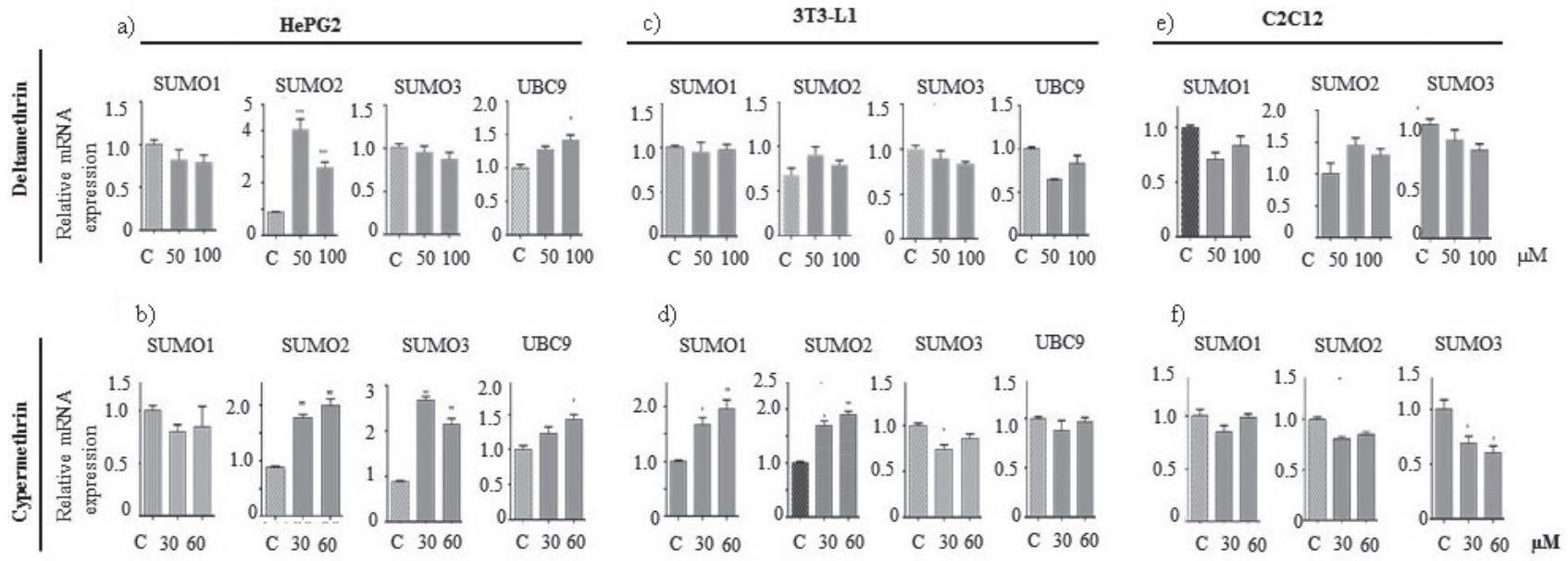

Fig. 4. (a-f) represents SUMO1, SUMO2/3 expression in various cell lines treated with deltamethrin or cypermethrin. (a and b) mRNA expression levels of SUMO1, SUMO2, SUMO3, and UBC9 in HePG2. Fig. (c and d) represents mRNA expression levels of SUMO1, SUMO2, SUMO3, and UBC9 in differentiated 3T3-L1 cell lines. Fig. (e and f) represents mRNA expression levels of SUMO1, SUMO2, SUMO3 in differentiated $\mathrm{C} 2 \mathrm{C} 12$ cells, treated with either deltamethrin or cypermethrin as quantified by real time qRT-PCR ( $\mathrm{n}=4$, $*=\mathrm{P}<0.05, * *=\mathrm{P}<0.01)$

expression of selective SUMO isoforms in the cell lines tested. Elevated expression of SUMO isoforms indicates the extent of stress created within the cell.

A number of studies have shown that UBC9 is upregulated in a variety of cancers and can serve as a biomarker [15-16, 36]. Our study demonstrates that UBC9 levels significantly increase in HePG2 on treatment with deltamethrin and cypermethrin. This observation is of significance in view of the fact that higher UBC9 levels were observed in certain cancers.

Elevated mRNA levels of IL-6 and IL-1 $\beta$ in differentiated adipocytes (3T3-L1) on treatment with deltamethrin and cypermethrin demonstrate the ability of these pesticides to trigger the inflammatory response.

In summary, elevated SUMOs and UBC9 and stress induction are indicators of conditions that are favorable for disease development, indicating that the extensive use of these pesticides is of concern.

\section{Conclusions}

SUMOs and UBC9 have an important role in cellular homeostasis as most of the cellular processes involve SUMO-modified target proteins. Deltamethrin and cypermethrin build up oxidative stress and influence SUMO and UBC9 expression.

\section{Acknowledgements}

We express our sincere gratitude to BMS engineering college and TEQIP II for funding, and Connexios life sciences (Bengaluru) for providing infrastructure for conducting experiments.

\section{References}

1. HAY R.T. SUMO: A history of modification. Mol Cell 18, $1,2005$.

2. JOHNSON E.S. Protein modification by SUMO, Annu. Rev. Biochem 73, 355, 2004.

3. KIM K.I., BAEK S.H., CHUNG C.H. Versatile protein tag, SUMO: Its enzymology and biological function. J Cell Physiol 19, 257, 2002.

4. LIANG Y.C., LEE C.C., YAO Y.L., LAI C.C., SCHMITZ M.L., YANG W.M. SUMO5, a Novel Poly-SUMO Isoform, Regulates PML Nuclear Bodies. Scientific Reports. 6, 26509, 2016.

5. HICKEY C.M., WILSON N.R., HOCHSTRASSER M. Function and Regulation of SUMO proteases. NIH Public Access 13, 755, 2013.

6. GALISSON F., MAHROUCHE L., COURCELlES M., BONNEIL E., MELOCHE S., CHELBI-ALIX M.K., THIBAULT P. A novel proteomics approach to identify SUMOylated proteins and their modification sites in human cells. Mol. Cell. Proteomics 10, M110.004796, 2011.

7. SAITOH H., HINCHEY J. Functional heterogeneity of small ubiquitin-related protein modifiers SUMO-1 versus SUMO-2/3. J Biol Chem 275, 6252, 2000.

8. MANZA L.L., CODREANU S.G., STAMER S.L., SMITH D.L., WELLS K.S., ROBERTS R.L., LIEBLER D.C. Global shifts in protein sumoylation in response to electrophile and oxidative stress. Chem. Res. Toxicol 17, 1706, 2004.

9. TEMPÉ D., PIECHACZYK M., BOSSIS G. SUMO under stress. Biochem Soc Trans 36, 874, 2008.

10. KIM H.J., YUN J., LEE J., HONG H., JEONG J., KIM E., BAE Y.S., LEE K.J. SUMO1 attenuates stress-induced ROS generation by inhibiting NADPH oxidase 2. Biochem. Biophys. Res. Commun 410, 555, 2011.

11. BETTERMANN K., BENESCH M., WEIS S., HAYBAECK, J. SUMOylation in carcinogenesis. Cancer Lett 316, 113, 2012. 
12. FLOTHO A., MELCHIOR F. SUMOYLATION: A Regulatory Protein Modification in Health and Disease. Annu Rev Biochem 82, 357, 2013.

13. SUBRAMANIAN D., RAGHUNAYAKULA S., OLSEN J.V., BENINGO K.A., PASCHEN W., ZHANG X.D. Analysis of changes in SUMO-2/3 modification during breast cancer progression and metastasis. J Proteome Res 13, 3905, 2014

14. RONEN O., MALONE J.P., KAY P., BIVENS C., HALL K., PARUCHURI L.P., MO Y.Y., ROBBINS K.T., RAN $\mathrm{S}$. Expression of a novel marker, Ubc9, in squamous cell carcinoma of the head and neck. Head Neck 31, 845, 2009.

15. WU F., ZHU S., DING Y., BECK W.T., MO Y.Y. MicroRNA-mediated regulation of Ubc9 expression in cancer cells. Clin. Cancer Res 15, 1550, 2009.

16. MOSCHOS S.J., JUKIC D.M., ATHANASSIOU C., BHARGAVA R., DACIC S., WANG X., KUAN S.F., FAYEWICZ S.L., GALAMBOS C., ACQUAFONDATA M., DHIR R., BECKER D. Expression analysis of Ubc9, the single small ubiquitin-like modifier (SUMO) E2 conjugating enzyme, in normal and malignant tissues. Hum Pathol 41, 1286, 2010.

17. ZHAO Z., TAN X., ZHAO A., ZHU L., YIN B., YUAN J., QIANG B., PENG X.MicroRNA-214-mediated UBC9 expression in glioma. BMB Rep 45, 641, 2012.

18. EI K., VERTEGAAL A.C.O. SUMOylation-Mediated Regulation of Cell Cycle Progression and Cancer. Trends Biochem Sci 40, 779, 2015.

19. GUO W., YUAN L., XIAO Z., LIU D., ZHANG J.X. Overexpression of SUMO-1 in hepatocellular carcinoma: a latent target for diagnosis and therapy of hepatoma. $\mathrm{J}$ Cancer Res Clin Oncol 137, 533, 2011.

20. Quality control of pesticide products, Guidelines for National Laboratories, [cited 2005] Available from : http:// apps.who.int/iris/bitstream/10665/69158 /1/ WHO_CDS WHOPES_GCDPP_2005.15.pdf

21. SPURLOCK F., LEE M. Synthetic pyrethroid use patterns, properties, and environmental effects. ACS Symp Ser 991, $3,2008$.

22. MORGAN M.K. Children's exposures to pyrethroid insecticides at home: a review of data collected in published exposure measurement studies conducted in the United States. Int. J. Environ. Res. Public Health 9, 2964, 2012.

23. ERDOĞAN O., CEYHUN S.B., EKINCI D., AKSAKAL E. Impact of deltamethrin exposure on mRNA expression levels of metallothionein A, B and cytochrome P450 1A in rainbow trout muscles. Gene 484, 13, 2011.

24. SAKAMOTO H., SAKAI E., FUMIMOTO R., YAMAGUCHI Y., FUKUMA Y., NISHISHITA K., OKAMOTO K., TSUKUBA T. Deltamethrin inhibits osteoclast differentiation via regulation of heme oxygenase-1 and NFATc1. Toxicol. In Vitro 26, 817, 2012.

25. SHAFER T.J., MEYER D.J., CROFTON K.M. Developmental neurotoxicity of pyrethroid insecticides: Critical review and future research needs. Environ. Health Perspect 113, 123, 2005.

26. WIELOGÓRSKA E., ELLIOTT C.T., DANAHER M., CANNOLI L. Endocrine disruptor activity of multiple environmental food chain contaminants. Toxicol in Vitro 29, 211, 2015

27. HU J.X., LI Y.F., LI J., PAN C., HE Z., DONG H.Y., XU L.C. Toxic effects of cypermethrin on the male reproductive system: With emphasis on the androgen receptor, Journal of applied toxicology 33 (7), 576, 2011.

28. SINGH A.K., TIWARI M.N., UPADHYAY G., PATEL D.K., SINGH D., PRAKASH O., SINGH M.P.
Long-term exposure to cypermethrin induces the nigrostriatal dopaminergic neurodegeneration in adult rats: Postnatal exposure enhances the susceptibility during adulthood. Neurobiol. Aging 33 (2), 404, 2010.

29. AMER S.M., IBRAHIM A.A., EL-SHERBENY K.M. Induction of chromosomal aberrations and sister chromatid exchange in vivo and in vitro by the insecticide cypermethrin. Journal of Applied Toxicology 13 (5), 341, 1993.

30. CARMICHAEL J., DEGRAFF W.G., GAZDAR A,F. Evaluation of a Tetrazolium-based Semiautomated Colorimetric Assay: Assessment of Chemosensitivity Testing Evaluation of a Tetrazolium-based Semiautomated Colorimetrie Assay. Assessment. Am. Assoc. Cancer Res 47, 936, 1983

31. ROSENKRANZ A.R., SCHMALDIENST S., STUHLMEIER K.M., A microplate assay for the detection of oxidative products using 2', 7' -dichlorofluorescindiacetate: J. Immunol. Methods 156, 39. 1992.

32. DELL E.J., GANSKE F. NADH and NADPH Conversion Monitored with BMG LABTECH's POLAR star Omega Microplate Reader. BMG LABTECH application note $\mathbf{1 7 0 .}$ 2008.

33. GRISHAM M.B., JOHNSON G.G., LANCASTER J.R Quantitation of nitrate and nitrite in extracellular fluids: Methods Enzymol, 268, 237, 1996.

34. SCHELLER J., CHALARIS A., SCHMIDT-ARRAS D., ROSE-JOHN S. The pro- and anti-inflammatory properties of the cytokine interleukin-6. Biochim Biophys Acta - Mol Cell Res 1813, 878, 2011.

35. NICOL L.E., GRANT W.F., COMSTOCK S.M., NGUYEN M.L., SMITH M.S., GROVE K.L ., MARKS D.L. Pancreatic inflammation and increased islet macrophages in insulin-resistant juvenile primates. J Endocrinol 217, 207, 2013

36. REHMAN H., MOHAN A., TABASSUM H., AHMAD F., RAHMAN S., PARVEZ S., RAISUDDIN S. Deltamethrin Increases Candida albicans infection susceptibility in mice. Sc and J Immunol 73, 459, 2011.

37. CAO Z., SHAFER T.J., MURRAY T.F. Mechanisms of pyrethroid insecticide-induced stimulation of calcium influx in neocortical neurons: J Pharmacol Exp Ther 336, 197, 2011.

38. MARÍA D., ORTIZ-PÉREZ., TORRES-DOSAL A., BATRES LE., OLGA D., LÓPEZ-GUZMÁN. GRIMALDO M., CARRANZA C., IVÁN N., PÉREZMALDONADO., MARTÍNEZF., URIZAR JP., BARRIGA FD. Environmental Health Assessment of Deltamethrin in a Malarious Area of Mexico: Environmental Persistence, Toxicokinetics, and Genotoxicity in Exposed Children. Environ Health Perspect. Jun; 113 (6), 782, 2005.

39. YANG W., WANG L., ROEHN G. Small ubiquitin-like modifier 1-3 is activated in human astrocytic brain tumors and is required for glioblastoma cell survival. Cancer Science 104, 70, 2013.

40. GOLEBIOWSKI F., MATIC I., TATHAM M.H., COLE C., YIN Y., NAKAMURA A., COX J., BARTON G.J., MANN M., HAY R.T. System-wide changes to SUMO modifications in response to heat shock. Science Signaling, 2 (72), 1, 2009.

41. BOSSIS G., MELCHIOR F. Regulation of SUMOylation by Reversible Oxidation of SUMO Conjugating Enzymes. Mol. Cell, 21, 34, 2006.

42. QU J., LIU G-H., WU K., HAN P., WANG P., LI J., ZHANG X., CHEN C. Nitric oxide destabilizes Pias 3 and regulates sumoylation. PLoS One, 2 (10), e1085, 2007. 